\title{
Professional identity and anxiety in architect-client interactions
}

Sumati Ahuja, Business school, University of Technology Sydney, Australia sumati.ahuja@uts.edu.au

Natalia Nikolova, Business school, University of Technology Sydney, Australia natalia.nikolova@uts.edu.au

Stewart Clegg, Business school, University of Technology Sydney, Australia

$\underline{\&}$

Nova School of Business and Economics, Lisboa, Portugal

stewart.clegg@uts.edu.au

Please cite as: Ahuja, S., Nikolova, N., and Clegg, S. (2019). "Professional Identity and Anxiety in Client-Architect Interactions." Construction Management and Economics. DOI $\underline{10.1080 / 01446193.2019 .1703019}$ 


\begin{abstract}
Large-scale construction projects increasingly have powerful and knowledgeable clients as project owners with whom professionals, such as architects, must interact. In such contexts, clients may have a significant impact on the constitution of a coherent and stable professional identity. Based on qualitative interviews with 50 architects across four large multidisciplinary professional service firms (PSFs) located in Sydney, Australia, supplemented by ethnographic observations, this article explores how architects constitute their identity in interactions with clients. The findings led us to conceptualize professional-client interactions in terms of two overarching discursive strategies deployed by architects in attempts to manage clients that are powerful and knowledgeable: best for client and best for project. We illustrate the anxieties that architects experience and suggest that attempts to secure professional identity may result in (re)producing an enduring sense of anxiety with unintended consequences for project outcomes and organizational performance.
\end{abstract}

Keywords: architects; professional identity; clients; discourse; identity work; anxiety 


\section{Introduction}

The concept of identity has enabled management and organization studies (MOS) researchers to observe and address a range of individual level issues associated with particular occupational roles. Significantly, researchers suggest that identity issues may affect professionals' performance within organizations. For example, van Marrewijk et al. (2016) argue that identity (being American or being Panamanian) was a major determinant of project outcomes in the new Panama Canal Megaproject. Nonetheless, despite this pioneering contribution, the different ways in which identity is performed are under-explored by scholars in construction management (Brown and Phua, 2011; Phua, 2013). As Liu and Walker (1998: 211) point out, this is an important omission because 'behaviour of the project organization (at the macro-level) is the aggregate of the project participants' behaviour (at the microlevel)'; thus, individual-level constructs can play a crucial role in the evaluation of project outcomes. The significant contribution of this article accords with the suggestion of Brown and Phua (2011) for the need to conduct more empirical work that is subject to sociologically informed theorizing on identity issues in construction management research. We do so by exploring how architects working on large-scale construction projects constitute their identity in interactions with knowledgeable and powerful clients. In this article, we adopt a discursive interpretive approach (Heracleous, 2004) to highlight the significance of client interactions on the constitution of professional identity. In so doing, we demonstrate the importance of 'identity issues' operationalized at the individual level of analysis for construction management debates (Brown and Phua, 2011: 83).

Based on 50 informal, open-ended conversational interviews with architects gathered during an eighteen-month ethnographic study of four multidisciplinary professional service firms (PSFs), we argue that professional-client interactions increasingly underpin how professional 
identity comes to be constructed. We demonstrate that interactions with clients generate significant anxieties for professionals that may not be resolved through identity work (Brown, 2017), which can have negative impact on professionals and organizations.

The paper is structured as follows. First, we review the literature on professional identity with a focus on the formation of architects' identity during formal training and its mismatch with contemporary multiorganizational contexts (Dainty et al., 2007) in which architects are increasingly engaged (Caven and Diop, 2012). This is followed by a brief overview of the central role that clients play in today's professional service organizations. We then outline how disparate studies illuminate ongoing anxiety in the workplace. After presenting our methodological and analytical choices we investigate the identity work of architects interacting with increasingly knowledgeable and active clients. We discuss the identity anxieties generated in client-interactions before concluding with the broader implications of our study for construction management research.

\section{Professionals in contemporary practice}

In early work on professions, autonomy and self-regulation were seen as the defining characteristics of professional identity (Thomas and Hewitt, 2011; Brown and Coupland, 2015; Robertson et al., 2003). Historically, the provision of professional services was characterized by an 'asymmetry of expertise' in which the client was reliant upon the expertise of the professional (Abbott, 1988: 5). As such, there were expectations of how professional work should be conducted, bound by codes of conduct and the expert authority of the professional (Muzio and Ackroyd, 2005). The term 'collegiate control' positioned professionals as more powerful than their clients (Johnson, 1972). By contrast, 'patronage' described situations in which clients defined their own needs and the manner in which they were to be met by the professional (Johnson, 1972). For example, the stately homes and 
palaces of the Renaissance (Lytle and Orgel, 2014) were built to realize a vision that the patron might have but which the architect delivered. The patron provided resources and a brief but typically did not presume to have project oversight.

Increasingly, professionals seek to exercise autonomy in complex project contexts involving a number of significant others, including clients, partners, contractors and regulators, delivering projects as a part of a broad-based collaboration (Dainty et al., 2007). In these multiorganizational contexts, powerful and influential clients (Dinovitzer et al., 2014; Gustafsson et al., 2017) participate in the development of 'shared understanding, norms, values and practice' with the professionals with whom they interact (Nikolova et al., 2009: 296). In the case of architects as one of the key players on construction projects, clients play an active role not just in terms of defining design and construction constraints but also in giving 'advice, and approval throughout the process, without which the appropriateness of the services is threatened' (Cuff, 1991: 171). In other words, powerful client organizations participating in large-scale construction projects influence professional practices (Handley et al., 2007), positioning professional-client relations as a key construct for understanding professional identity (Caven and Diop, 2012). In changing organizational contexts where multiorganizational clients are the sources of patronage, notions of autonomy in the control of professional work are becoming increasingly outmoded (McGivern et al., 2015). Particularly for architects, their "position in the "value chain" [...] has changed from being the client's representative located between the client and all the other members of the project coalition to reporting to a project manager' (Winch and Schneider, 1993: 469). Construction projects are thus well suited for examining the processes and consequences of identity work due to their transient, multiorganizational, multi-stakeholder contexts (Phua, 2013).

\section{Architects identity}


Architects have traditionally led the design team and been perceived as the 'spiritual leader' of the project (RIBA, 2015). Despite reports that the profession's authority over clients has been on the decline for decades (Waite and Braidwood, 2017), the training of architects continues to emphasize the role of individual creativity and aesthetic originality (Winch and Schneider, 1993) such that ' $[\mathrm{b}]$ ecoming an architect is about becoming an artist, but a peculiar kind of artist who stays within certain boundaries' (Cuff, 1991: 154). Design teaching in architecture schools tends to focus on theory and individual creativity unfettered by client demands (RIBA, 2015). Although Cohen et al. (2005) suggest that architects identify with three entangled roles, those of creative person, business person and humanitarian, stereotypical notions of the architect as a creative and passionate genius (Heynen, 2012) permeate the expectations of junior architects (Ahuja et al., 2019). As such, the ethos of design as distinctive self-expression is highly disciplined and 'internalized in the professional socialization of many architects' (Brown et al., 2010: 530). Architectural researchers have argued that the image of the architect-as-lone genius remains tacitly embedded throughout the profession (Wiscombe, 2006; Cuff, 2012; Pelkonen, 2012), reinforced by architectures' highest accolade, the Pritzker Prize which continues to honor the hero architect unbridled by client needs or budgets (Heynen, 2012). Despite industry calls for business and finance to be taught as standard within architecture schools (Farrell, 2014: 29), design as creative practice continues to be the core of architects' self-understandings. Thus, architects' 'ideal' professional identity is preconfigured through specific discourses inculcated during long periods of formal education and socialization. For Murtagh et al. (2016: 69), architects 'invest the self in their designs' such that the outcomes of their design may be 'experienced as an extension of the physical self'. In other words, architects derive a 'sense of self-identity' from design. 
In the three decades since the seminal studies of the architectural profession (Blau, 1987; Cuff, 1991; Larson, 1993; Gutman, 1988), architectural practice has evolved 'from the auteur to the multinational full service firm' (McNeill, 2009: 3). In the UK, the role of architects in the construction industry has been the subject of intense governmental scrutiny (Egan, 1998; Farrell, 2014), broadly under the remit that 'architects need to be part of the production process of buildings' (Cohen et al., 2005: 777). In particular, the proliferation of large publicsector projects with multiorganizational clients has significantly altered traditional procurement methods, the contractor's managerial role and increased the portion of design work being carried out by subcontractors, transforming the social context in which architectural design and production takes place (Latham, 1994; Jamieson, 2011). Moreover, increasing use of collaborative relationships such as partnering, joint venture, alliances and private public partnerships have replaced traditional procurement methods (Akintoye and Main, 2007). Typically, in these days of major city building projects, architects work in collaboration with large property developing organizations, government agencies and other complex client systems 'comprising several different interest groups whose objectives differ, and may well be in conflict' (Green, 1996: 156).

Traditionally, architects have sought to project a professional identity anchored in perceptions of design expertise and aesthetics. In this way, they aim to (re)construct 'a continuous, stable identity' (Gill, 2015: 308). Interactions with knowledgeable clients, however, provide both constraints and opportunities for the constitution of continuous, stable professional identity. This is because corporate clients' expertise often matches that of the highly qualified professional. On the one hand, less time can be spent in negotiating and navigating the interaction of different world views. On the other hand, clients' knowledgeability may lead to professionals' practices and identity being questioned. When this occurs, professional identity becomes 'mediated through a wide range of controls, 
demands and expectations' (Knights and Clarke, 2018: 149). These externally interpreted controls either become adopted in a self-disciplining fashion, potentially entailing 'significant social and personal costs' (Haines and Saba, 2012: 122), or if resisted, risk the credibility of professional identity as contracts fail to be agreed. As Vough et al. (2013: 1050) point out, 'misalignments between what professionals perceive as the content of their professional work and what they believe others think constitutes professionals' work' can lead to emotional costs with broad implications, for both individual professionals as well their employing organizations.

\section{Professional identity, identity work and anxiety}

Professional identity is 'the relatively stable and enduring constellation of attributes, beliefs, values, motives, and experiences in terms of which people define themselves in a professional role' (Ibarra, 1999: 764). The content and processes of work are central to professional identity construction and thus, 'achieving alignment between professional identity and work is a fundamental motivator of identity construction' (Pratt et al., 2006: 225) associated with ontological security (Allan et al., 2018). Similar to the construction of professional expertise (Chan, 2016), the construction of professional identity is ongoing and involves work 'that underpins the identity process, [and] draws upon a range of meanings which individuals can identify with or resist' (Gill, 2015: 307). In this view, professional identity is 'formed in relation to significant others' through 'situated practices of language use' (Brown, 2017: 15). The emphasis is on dynamic relations between macro-level changes and individuals' discursively constructed identities (Ainsworth and Hardy, 2004;

Sveningsson and Alvesson, 2003). By focusing on identity work in situated social contexts, the importance of 'forming, repairing, maintaining, strengthening or revising the 
constructions' of self-meanings is highlighted (Alvesson and Willmott, 2002: 626), bridging macrolevel changes with their microlevel correlates.

Professionals' identity construction has been conceptualized as an ongoing struggle (Sveningsson and Alvesson, 2003; Ahuja et al., 2017) that may have unintended consequences, posing salient issues for construction management research. Ahuja et al. (2019), for example, found that for junior architects employed in PSFs, identity work may lead to a sense of disillusionment and the constitution of a dejected professional identity. Others have noted the 'unintended downstream consequences' (Caza et al., 2018: 901) of identity work such as, self-doubt (Beech, 2008), anxiety, and heightened insecurities over maintaining an elite status (e.g. Gill, 2015; Collinson, 2003; Knights and Clarke, 2014; Sturdy, 1997). Notably, emotional attachment to the expert identity of the professional may lead to acute anxiety 'about meeting the challenging expectations necessary to sustain their [professionals'] sense of self' (Gill 2015: 320).

A more nuanced understanding of the lived experiences of professionals that lead to anxiety, cynicism and burnout is timely because studies have shown that a high number of construction professionals (e.g. engineers and project managers) suffer from ongoing anxiety (Haynes and Love, 2004; Lingard, 2003). For example, an occupational stress study in the construction industry found that nearly $70 \%$ of construction professionals suffer from stress, anxiety or depression with 'conflicting demands' identified as one of the main causes (COIB, 2006). As De Silva et al. (2017: 488) argue, '[t]he construction industry has long been recognized to be a stressful industry, due to its complexity' and 'many professionals including project managers, architects, engineers and quantity surveyors have to work under pressure'. 
Taking into account the critical role clients play in today's professional service organizations, professional-client interactions provide a suitable context for the study of anxiety in the workplace. Despite a spate of studies examining the roles and relationships of the various professions in the construction industry (e.g. Caven and Diop, 2012; Wade et al., 2017), 'construction industry researchers tend to oversimplify the role of the client' (Cherns and Bryant, 1984: 177; Havenvid et al., 2016; Green, 1996). Understanding the influence of client interactions on professionals working in the construction industry is important because identity challenges generating anxiety can have significant implications for individuals' wellbeing and quality of life (Ashman and Gibson, 2010). On an organizational level, such anxieties can lead to loss of productivity, increased employee turnover and loss of talent, while at the societal level, mental health issues caused by anxiety have significant financial implications (Collinson 2003; Gill 2015; Knights and Clarke 2014). Building on these insights, we examine the identity work of architects as they interact with increasingly knowledgeable and active clients. Our study reveals how architects seek to address the challenges they face in their interactions with clients and to give meaning to the work that they do.

\section{Data and Methods}

In this article, we draw on semi-structured open-ended conversational interviews conducted during the course of 50 architects' daily activities to focus on how professional identity is constituted in interactions with clients. Of these architects, 28 were male and 22 females. Two participants are renowned architects who have won several professional accolades and hold prestigious positions in professional associations and universities (see Table $1 \& 2$ for participant information). The interviews were conducted during a broader ethnographic study of four multidisciplinary professional service firms, over an eighteen-month period between 
July 2015 and December 2016, in Sydney, Australia. The interviews took place at the interviewee's place of work and ranged in length from 30 minutes to 90 minutes. All interviews were recorded and transcribed. On average, each interview transcript had a length of 7000-9000 words. The interview data presented in this paper covered a spectrum of architects that ranged in professional tenure from 5 to 40 years, all of whom were engaged in large-scale construction projects. Table 2 shows the years of professional experience of the architects.

\section{Table $1 \& 2$ about here}

Prior to the interviews assurances of anonymity and confidentiality were provided and informed consent secured. All respondents were asked to describe the types of clients they engaged with in their daily work routines. While we prompted the respondents to provide accounts of their work as well as their experiences and interpretations of client interactions, the open-ended nature of conversations gave these architects opportunities to reflect on interactions with clients. Our aim was 'to stimulate active narrative production, intentionally provoking interviewees to articulate and reflect upon their position' [here professional identity] (Hodgson et al., 2015: 749) with respect to interactions with clients. The interviews enabled us to 'situate the observations in the broader temporal and spatial context' (Groleau et al., 2012: 655) and provided a 'setting for stimulating professional identity reflections' (Reed and Thomas, 2019: 5).

The analysis of our data involved several interrelated stages in order to develop appropriate themes and advance insights about the ongoing tensions that individuals faced in negotiating professional identity in their interactions with clients for, as Breakwell (2010: 6.3) states, 'people are normally self-aware and actively monitor the status of their identity'. Taking a discursive-interpretive approach to identity work (Ainsworth and Hardy, 2004; Brown, 2017) 
which 'focuses on individuals' active construction of identity in social contexts' (Pratt et al., 2006: 237), we shed light on the ways in which architects perceived client interactions in relation to their professional identity. As Caza et al. (2018: 891) explain, '[d]iscursive identity work is comprised of what is verbalized and how it is verbalized' through 'narratives, stories, dialogues, and conversations as a conduit for identity work'. Discursive approaches have been increasingly deployed in construction management research (Sherratt et al., 2013; Ness, 2010) providing new insights into how the identities of professionals constructed through their stories and narratives shape material practices (e.g. Sergeeva and Green, 2019) and have an impact on the wellbeing of professionals.

Data were analysed using an abductive approach (Peirce, 1934: 171) in which 'abduction is the process of forming an explanatory hypothesis'. First, after an initial review of the data, we open coded both for the challenges and opportunities the architects experienced in their interactions with clients. These orientations were mapped by going back and forth between relevant literature and empirical data (van Maanen et al., 2007). The key theoretical concepts we drew upon as we coded the data included professional autonomy and control (Abbott, 1988); patronage and the role of the client (Johnson, 1972); the active construction of professional identity in social contexts (Pratt et al., 2006) and the role of identity work in mediating challenges to identity (Brown, 2017). We then synthesized in a 'descriptive yet comprehensive fashion the experiences that participants discussed' (Petriglieri et al., 2018: 7). The common themes that emerged across the four firms in the accounts of the respondents were first, the identity challenges architects experienced in their interactions with knowledgeable clients and second, how these challenges were having an impact on their selfviews and their responses to these challenges. Further analysis led to the aggregation of these descriptions into two overarching discursive strategies that architects deployed, simultaneously, to manage their clients. These were, best for client and best for project. 
Surprisingly, our data showed that these strategies generated significant and ongoing anxiety. In presenting our analysis in the following sections, we sought an approach that would be suitable to demonstrate some of the contextual richness of our data such as illustrative stories.

\section{The Architect-Client Conundrum}

Architects' accounts of their work reflect exogenous changes that have had a significant impact on architectural practice, crystalizing the salience of knowledgeable and sophisticated clients that have now become a permanent feature of architectural work in PSFs. In our data, despite the participants being based in large 'design' firms led by well-known architects, the artistic and aesthetic priorities of architects, that is, professional values (Bos-De Vos et al., 2016) 'to have a design that we are proud of' (senior associate, Firm 3) were often misaligned with clients' priorities and views on architectural work as a technical service. The strong desire to uphold design priorities on large-scale projects involved considerable personal struggles for participants:

they want to start building... and we're still developing the design...that's how a lot of the problems start...then it feels like we're playing catch up...they build so fast...things go up overnight...clients just don't get it. (project architect, Firm 2)

For some, the 'constant battles' with clients' priorities, often concerned with speed, costs and area of lettable space, versus architects' professional values led to disappointments over their chosen career:

we [architects] insist upon aesthetics...any excuse to do something interesting...but clients have other priorities... that's stressful.... that keeps me up at night. (senior associate, Firm 4) 
When discussing their interactions with clients, respondents described their clients as, 'experts', 'sophisticated', and 'savvy'. For example:

[our clients] are sophisticated developer types...you know like they have...MBAs from Harvard. (senior associate, Firm 1)

[our clients are] all experts [gives example] they have 12-15 people [during feasibility study phase] who are all experts, geo-techs [geo-technical engineers], specialist contractors, structurals [engineers] and such like. (project architect, Firm 2)

Dealing with complex client systems on large scale projects was often described as 'complicated' and had a number of implications for architects' identity construction. As this renowned architect explained:

the client might range from an individual to a corporation to the public to the future generations to an entire government...and so understanding that and dealing with that... it's complicated (renowned architect, Firm 1).

Despite the firms' past achievements for 'award winning architecture', 'innovative designs' and the reputational capital (e.g. Bos-De Vos et al., 2016) that positions their work as a predominantly creative venture (Brown et al., 2010; Blau, 1987; Larson, 1993), architects felt 'undervalued [by clients] in terms of what we [architects] can offer' (senior associate, Firm 1). The main implication of client-interactions was the ongoing anxiety of having to:

constantly justify the role that you have [as architect]...you have to explain every [design] decision. (senior associate, Firm 3) 
This situation is far removed from the ideal of professional autonomy and control (e.g. Abbott, 1988). Being constituted as a service provider in client-interactions stands in stark contrast to (simultaneous) claims of ideals, such as: 'I think we're [architects] the only ones in the project [team] that can visualize the whole [project]...from the big picture right down to the balustrade detail' (architect, Firm 1). These comments highlight the disjuncture between the power relations that architects have traditionally enjoyed, as experts (e.g. Johnson, 1972) who can 'visualize the whole project', versus their inability to explain the value that they bring to the client. While many respondents were quick to point out that 'clients don't like the artist label they prefer to see us as technicians', claiming the identity of an architect in largescale projects is riddled with anxiety.

The increasing project orientation of architectural work as a bundle of services that extend over a long period of time, absorbing a large amount of resources and time, means that 'getting the next job' was often the central concern of senior architects. Yet, the firms devoted considerable time and resources to entering design competitions, that often came with a low fixed fee, 'a stipend really' (senior associate, Firm 2), that did not compensate the resources and hours spent. Design competitions were highly cherished because they were: (1) a relatively autonomous and self-contained endeavor; (2) did not involve clients and, most importantly; (3) were judged by a jury of esteemed peers. As such, even though providing a service to a client is the lifeblood of PSFs, unbuilt designs were highly valued for embodying the design and artistic values of architects. As Kreiner (2009) suggests, design competitions are both opportunities for gaining work and fame as well as for celebrating architects' creative and aesthetic skills. Indeed, the results of competitions are widely published and reviewed in the architectural press. However, architects' identity that emanates from 'feeling proud of our work' and 'good design' for the 'public good' (Duffy and Rabeneck, 2013), is 
challenged by feelings of being misunderstood and undervalued by clients with different priorities leading to the experience of intense anxiety.

In the following, we explicate two overarching discursive strategies that architects deployed in attempts to manage relations with their organizational clients who increasingly influence the architectural design process. These discursive strategies; best for client and best for project, understood as ways in which [we] 'describe ourselves and our work' (Fine, 1996: 90) are related to architects' self-views (identity) and not just what they do, as they seek to construct a sense of agency in interactions with clients. However, we find that anxiety is experienced through self-defeating attempts to preserve and stabilize a professional identity that appears incongruously out-of-date in contexts where architects have increasingly less autonomy in procurement and construction processes (Waite and Braidwood, 2017).

\section{Best for client}

In large-scale construction projects where clients are experts with objectives that are often at odds with those of the architects, respondents described what it meant to be an architect by positioning themselves as endorsing clients' ideas. In doing so, architects signaled that they accept client's authority over design decisions. Participants talked of endorsing design ideas initiated by clients as identity-affirming. As this respondent explains:

Clients will look to me for endorsement......so we might say we've exceeded the height here and they might look at me and '[name] do you think council's [regulatory authority] gonna go for that?' and I'll say I think these are the issues...or they'll say, '[name] are you happy with the design?' (director, Firm 1) 
In these accounts, the respondents underplayed their autonomy because professional success and personal fulfillment derived from validations from clients since, 'knowing that I did what's best for the client gives me a great deal of well... personal satisfaction' (project architect, Firm 4). When reflecting on their professional identity on such projects, architects sought to present themselves as valuable contributors to the project by endorsing clients' ideas that helped clients meet their own needs (Johnson, 1972). Positioning the value of their services as endorsing design that may well have been client initiated, ensured that significant clients continued to rely on architects for advice. Notably, this discursive strategy provided external validation for professional identity since their clients were often described as 'very challenging'. During fieldwork, the researcher observed a one-hour presentation to a developer-client during which several design options were presented. The architect explained the regulatory and structural constraints that had led to the architects' 'preferred' design option, but the client was unconvinced and began to draw shapes on the section of the drawing that was being discussed. The architect later explained that this developer-client had trained as an architect, making him:

a good client but very challenging and [he'1l] come to a meeting with new ideas and almost turn the thing [design] on its head (director, Firm 4)

In this discussion the primary role of the architect was to listen to the client's idea to alter the shape and form of the building by lowering the height while extending the lower levels outward, for which the client sought an endorsement from the architect.

Accepting that interactions with clients' challenge architects' identity was a key theme that emerged in the data: 
sometimes you gotta accept that things through that method won't necessarily be the same as if you had absolute control and absolute decision [making] of design. (renowned architect, Firm 2)

Being able to endorse clients' design-ideas was one strategy architects deployed to address the erosion of their autonomy (e.g. turning 'design on its head') in interactions with knowledgeable clients. Additionally, respondents found themselves providing clients with constant reassurances 'as to why we're making those design choices...well mainly we have to reassure them...yeah lots of that reassuring.... that the design [decision] is what's best for the client' (director, Firm 1). Central to this understanding was the notion that architects were doing what is 'best for the client' despite working for clients 'that are not on same wavelength...I mean... in appreciating the value of good design' (project architect, firm 3). This kind of subterfuge, however, came with emotional costs, that is, anxieties triggered by having to do what the clients expect and require versus what architects see as most important. Indeed, this disparity was a significant source of anxiety:

The tension or the difficulty is just speed...the speed at which people [here, clients] want things resolved I don't think it's... it's not really possible to resolve design... well that quickly. (director, Firm 2)

These 'constant battles' to accommodate clients' ideas and expectations (here, speed and cost) versus designing something 'that works and is aesthetically pleasing' (director, Firm 2), generate threats for architects' identity that provoke considerable anxiety. For instance:

look... some clients don't really give a shit about architecture or buildings, in the case of [gives example] they [clients] were under pressure [by new regulations] to improve the building envelope...they didn't want to spend the money... but they needed us [for a building permit] so we're already undervalued to start with. (director, Firm 1) 
Anxieties about being undervalued, prevalent throughout the profession are internalized by practitioners, because the clients 'don't care about architecture' (director, Firm 1) per se:

I want to do good design but it's a constant battle .... we don't have time to think you know... I feel like a machine. (junior architect, Firm 2)

For this respondent, the harsh deadlines set by clients generate a great deal of anxiety expressed as a 'constant battle' in which delivering drawing packages to deadlines stymies his desire to 'do good design'. Here, the respondent, feels 'like a machine' rendering the architect unsure of his competence in a fiercely competitive marketplace. This junior architect (Firm 3) had similar experiences:

so, you are trying to portray the importance of design but at the end of the day they [the client] say ... 'can you just replicate that [propriety system]?' that's when you go Arhhh ... Grrrrr ...here we go ... so what the fuck am I doing?

For this respondent, the disappointment of having to replicate a propriety system (that is, product assemblies that can be bought) instead of providing the client with innovative design solutions generated frustration and anxiety about the work that he was actually doing. Similarly, this respondent questioned whether clients value their work at all, since original ideas were often completely overturned:

[client said] 'we're not building that we're building this...I want you to document this... coz I've spoken to the [stakeholders] and we're gonna sell them the bottom part of the building ...make enough money to pay for that [the top part]'. (director, Firm 2)

In these accounts, constantly having to reassure clients that architects' decisions are what's best for the client, that is, architects understand clients' commercial interests, exacerbate anxieties that surround the precariousness of architects' identity: 
[we] have to obviously provide matrices that indicate that we've have looked at all the different issues ...you know, we're pushing the aesthetic, but you have to tick every other box to prove that the aesthetic doesn't rule over any of the other issues. (senior associate, Firm 3)

Here, by 'providing matrices' architects have to demonstrate the balancing of design innovation with commercial sensibilities that some respondents described as 'submitting to the circus' (architect, Firm 2). In these comments, architects have to establish not just that their design would stand but also that it would be affordable because design is often seen by clients as something 'expensive' and largely 'dispensable'.

In summary, despite arguing that they derive pride and satisfaction from endorsing clients' design-ideas and reassuring clients that architects' decisions were 'best for the client', significant anxiety is experienced in client-interactions. The reason is that 'design' has become a devalued currency since construction technology has advanced, such that product assemblies or packages can be bought (off the shelf) rather than designed.

\section{Best for project}

Part of affirming the architects' identity as a distinct player in large-scale projects was the notion that:

A good project [that] is well designed it's not enough just to make money on it...we do expect to make money we do...but I think if you put your name to things... you need to be proud of the project'. (senior associate, Firm 2)

In these accounts, respondents downplay their professional identity as businesspeople. Instead, 'good design' enables architects to be proud of their projects and is acclaimed as creative and innovative, emphasizing the conceptual quality of architectural work. Indeed, 
respondents stressed that reminding clients that they are design experts and 'this is what you hired me for' enabled them to negotiate effectively with clients on difficult issues. For instance, this architect points out:

our role is ...giving the clients a bit more as an option to complete something they may not have looked at because their specialty is not architecture... and remind them that they can also participate [in project design]. (senior associate, Firm 4)

Here, the emphasis on reminding the clients to participate in 'design' is a means of regaining architects' standing as experts. Similarly, another respondent explains:

well we...nourish them [client relationships] so ideas can sink in and could be developed...I'm constantly reminding the client... we look at the big picture...I mean what's best for project. (project architect, Firm 1)

I think we should do what's best for the project rather than any individual [client] so that'll be the basis of the discussion... that's how you get work in the long term...you act in [the] project's interest not just the client's interest, the project's interest. (senior associate, Firm 3, emphasis in original)

Another way in which architects affirmed their identity vis-à-vis their clients was by being able to persuade clients that certain design elements (spatial and material) were crucial to the overall aesthetic design and thus, 'best for the project', despite being at odds with clients' original expectations. For some, knowing that 'we fought to get the best outcome [design]' (architect, Firm 4), was a source of satisfaction. For others, subtly persuading clients to come onboard with new design ideas, that is, 'being able to look at the big picture' affirmed architects' identity. These strategies were aimed at (re)establishing the architects as experts that clients relied upon (Abbott, 1988). 
At the same time, respondents pointed out that their 'commitment to the project design' exacerbated anxieties about identity. The burden of constantly making identity-defining choices led to 'feeling exhausted', having a 'loss of confidence', 'feeling insecure', 'worrying' and 'doubting myself'. The disparity between being who architects sought to be in the project process and who they were supposed to be, generated a 'state of perpetual angst (anxiety)' (Ashman and Gibson, 2010: 5). For example, following the observation of what appeared to be an hour-long argument, a renowned architect (Firm 2) later explained that:

we've had a lot of arguments...parts of the buildings are too high... and in the end, I looked at it and said we should lower some parts and not others which means they'll [client] have less development ....and he [client] cares about the project enough to say 'OK' ...but then he'll come back and say, 'now find the floor space somewhere else'.

Here, the developer-client is someone who is clear about his objectives and imposed constraints, eroding the architect's autonomy. By persuading the client that the architects' design-decision was 'best for the project' the client, is more willing to defer to the expert judgment of the architect. However, this often meant fighting for the identity they claim:

now that [meeting] was a tricky negotiation... at the back of mind, I know we fought to get the best outcome [design]... so you design the option that they [client] will accept and then obviously you make that as best you ...I try to frame it that we've come at the best option for the...project. (senior associate, Firm 3)

In this account, the architect re-narrates the initially heated exchanges as a 'tricky negotiation', in which the architect worked with the client to find an option that the architect deemed 'the best option' for the project. In this meeting, a compromise was agreed between the client's intention (to cut costs) and the architect's intentions (design). In these accounts, 
'getting work in the long term' was not simply a matter of satisfying clients' requirements but rather giving the clients several 'design options' to meet their requirements.

A similar view is expressed by this architect (Firm 4):

the clients had to save [\$4 million] ... so we made lots of design changes...it's not what we wanted but...we did it. In the end, they "found the money" ...so all that work...convincing the clients [that] this was the best option for the project ...was a good thing.

The effort of 'nourishing client relationships so ideas can sink in' (director, Firm 2) was also a source of anxiety because, 'you have to remind clients all the time...that you're not just dealing with aesthetics but that you have whole lot of experience built up from past projects which they might not know about' (director, Firm 2). These accounts are riddled with anxieties about being devalued; clients cannot be persuaded of the value of architects' services in large-scale construction projects. For example:

suddenly the [client's] brief will change so [example] we got to [] quite a long way into the project [ 8 months] and then the brief completely changed but rather than saying 'oh that's a variation because that wasn't the project we signed up to do' we... just modified that...or started again or whatever [] ... they [clients] didn't have the perception that design matters ...didn't really want to pay for [our] design... didn't care about [design] ideas they just wanted the building! (senior associate, Firm 4)

Similarly, this architect described how the constant changes they were asked to make throughout the project process caused significant anxiety:

They're [clients] still making changes to what we're doing after ... after 5 years...the buildings been under construction for almost 3 years [the project is almost complete]. 
Now it's been fitted out and someone's come along and said, 'oh we should do this'...We're about to hand over the project and they're still getting us to change things. I worry... a year from now someone will wanna change something...will they even come to us? (director, Firm 1)

The feeling of vulnerability was pervasive in the accounts of architects. This respondent was admitting he was anxious about whether the clients would ever be satisfied with the building design. Surprisingly, although architects were well aware of the sense of ongoing anxiety, they were unable to render their identity secure through identity work strategies and instead, seemed complicit in the inertia around identity change vis-à-vis their clients.

\section{Discussion}

The contemporary construction industry context (Dainty et al., 2007) is transforming roles, responsibilities and work interactions that challenge the constitution of a coherent and stable professional identity. Moreover, professionals are facing a decline in public confidence regarding the value of their exclusive knowledge base (Vough et al., 2013; Duffy and Rabeneck, 2013). As Duffy and Rabeneck (2013: 120) explain, 'the success of architects depends on the value placed on their intellectual capital by various kinds of client, i.e. those who wish to build'. Yet, due to outmoded professional structures and the ever-increasing rationalization of procurement processes, 'the professional relevance of architects is declining as they have now become one of many professionals providing [design] services to clients' (Frimpong and Dansoh, 2018: 293). Studies conducted in the UK (RIBA, 2015), Australia (Ahuja et al., 2017), France (Caven and Diop, 2012) and other countries (Frimpong and Dansoh, 2018) confirm that marginalization of architects and the invasion of their professional role in construction projects is pervasive across different scales of engagement, from house building to large-scale projects. A recent report by the Royal Institute of British 
Architects points out that, as projects advance, clients perceive architects' 'creative flair' or conceptual skills as a liability and may seek to replace the concept or design architect with a 'safer pair of hands' once the design development stage is completed (RIBA, 2015: 27). Since identity is a central lens that individuals use to make sense of and enact their environments (Lepisto et al., 2015), such perceptions by clients serve to undermine the constitution of a stable and enduring professional identity.

\section{The influence of clients on professional identity}

All our respondents defined themselves as architects, regardless of their hierarchical position in the firm. As such, they took great pride in showing the researcher the projects they were working on as well as the awards that the firms had won. In accordance with Bos-De Vos et al. (2016) who suggest that architectural firms spend extra time creating aesthetic qualities for projects that do not necessarily add any value for the client or user, but rather contribute to the creation of professional values (such as, reputation and work pleasure), we found that architects constructed a positive identity from their innovative designs of large-scale public domain projects. However, we found that these architects seemed confused about how to define their identity since clients increasingly 'dictate to the architect not simply the services the firm is supposed to perform, but more to the point, the services the firm will be allowed to perform' (Gutman, 1988: 58). In our data, the confusion was expressed as anxieties related to feelings of being undervalued by clients.

We have demonstrated that architects deployed two overarching discursive strategies; best for client and best for project in attempts to manage the challenges generated during interacts with powerful and knowledgeable clients. By endorsing clients' design-ideas and reassuring clients that architects' decisions were 'best for the client', architects sought to present themselves as valuable contributors to the aims and objectives of clients. Yet, significant 
anxiety due to 'concerns about being devalued' remained (Jensen, 2006: 97). In deploying the 'best for project' strategy, architects 'saw themselves as helping to improve the built environment for everyone' (Cohen et al., 2005: 791). Effectively, they were attempting to please the collective or ultimate client (Schein, 1997) thus, affirming their identity as experts that contribute to public good through the considered design of the built environment (e.g. Duffy and Rabeneck, 2013). In this sense, the data presents mixed views of architects' identity. On the one hand, architects depict their position as one of change, as a profession under threat in an era characterized by increasing skepticism from knowledgeable clients. The changing client demands are seen to be triggering identity work for architects as they strive to manage changing relations of practice. On the other hand, in terms of generating a new identity, we found that 'extant knowledge and practices [...] create mental blocks' that may be constraining (Miron-Spektor and Erez, 2017: 9). It was as if architects refused to acknowledge that the changing nature of their work requires a shift in their professional identity. While it has been argued that 'not finding opportunities to behave in accordance with one's desired identity leads to changes in the salience of such an identity' (Anteby, 2008: 204), our findings contradict this view. We suggest that architects' attachments to particular notions of professional self (Collinson, 2003) seemed to reinforce rather than resolve anxieties in relation to powerful clients. Similar to lawyers acquiescing to the influence of clients on partner promotions (Gustafsson et al., 2017), we were particularly struck by the lack of critical reflection by architects. Researchers have noted that, construction practitioners' ability to reflect on their expertise is 'dictated by professional associations or discourse created within the construction industry and its legal and economic imperatives' (Kanjanabootra and Corbitt, 2016: 573). We found the mismatch between the idealized professional identity inculcated in the long training and socialization of architects 
and what architects actually do, exacerbated identity anxieties in client-interactions (Samuel, 2018).

Indeed, discursive constructions of 'the client' exert a great deal of influence on professionals' sense of personal grooming, appearance and behavior (Becker et al., 1961). Displays of enthusiasm (Grey, 1998), emotions (Hochschild, 1983) and commitment (Anderson-Gough et al., 2000; Kuhn, 2009) become discursively constructed through interactions with significant others (Goffman, 1959). These discursive constructions provide justifications which, on the one hand, mediate tensions arising from 'being a professional' in contemporary contexts and on the other hand, constitute a professional identity that renders individuals governable, '[i]n a manner which feels like 'choice' (Anderson-Gough et al., 2000: 1168; Dick and Hyde, 2006). Considerable research in this tradition has foregrounded both the disciplinary effects of discourse (e.g. Alvesson et al., 2008; Gill, 2015) and the sophisticated agency of professionals in appropriating available discourses as they seek to reconcile professional identity misalignments (Wright et al., 2012; Brown et al., 2010; Pratt et al., 2006). Our discursive focus adds to a more nuanced understanding of the influence of clients in construction management research (e.g. Cherns and Bryant, 1984) by identifying the specific identity work strategies that architects use for managing active and knowledgeable clients on large multiorganizational construction projects. Our research also connects to broader discussions of expertise (e.g. Kanjanabootra and Corbitt, 2016; Chan, 2016) as an effortful accomplishment in constant flux, situated in everyday interactions and practice.

\section{Identity work, clients and anxiety}

Our research has demonstrated that interactions with clients (re)produce significant anxieties about the constitution of professional identity. Identity work has been conceptualized as a 
'precarious accomplishment' laden with complex emotions such as anxiety, fear and selfdoubt when established notions of identity are called into question (Beech et al., 2012; Beech et al., 2016; Gill, 2015; Knights and Clarke, 2014). Disparities between individuals' actual and ideal self can trigger identity work that may not always resolve challenges to identity and thus may also be seen as 'a double-edged sword, resulting in both positive and negative personal outcomes' such as, (re)producing an enduring sense of anxiety (Caza et al., 2018: 900) and emotional exhaustion (Haines and Saba, 2012). Knights and Clarke (2014) argue that workers experience anxiety 'because the self is fragile' requiring the confirmation of 'others' for identity construction in the workplace. We extend these understandings by demonstrating that interactions with clients generate significant anxieties, that may not be resolved through identity work.

In the case of the architects we studied, this anxiety was not simply about losing the client but about the 'dilution' or 'usurping' of design ideas by clients and the effect this had in undermining 'the autonomy upon which a dignified sense of [professional] self depends' (Knights and Clarke, 2018: 149). These understandings are important, since anxieties as a condition and consequence of identity work (e.g. Knights and Clarke, 2014) have implications beyond identity. They extend to issues of productivity, with consequences for the organizations in which professionals are increasingly embedded (Caza et al., 2018: 900) as well as for mental well-being in the workplace (Ashman and Gibson, 2010). In particular, anxiety in the workplace can harm individuals' well-being with significant financial implications for the wider society (Gill, 2015). In light of these understandings our study offers a rare glimpse of the anxieties of architects generated during client-interactions.

\section{Limitations and future research}


While our in-depth study provides new understandings of how individuals negotiate professional identity in relation to clients, this is also a limitation. We have only examined architects working in large PSFs. Although researchers have suggested that professionals may choose to locate within large firms because of the superior monetary rewards and resources, this in turn may restrict the opportunities to enact a desired identity available to architects working in small firms or as sole practitioners. In particular, because architects work closely with other professionals in the fiercely competitive construction industry, they may be more susceptible to being bypassed by clients for whom alternative service providers are available. Through future research scholars could compare and contrast other professionals to highlight ways in which client interactions influence the constitution of professional identity. Second, the study has focused on shared themes that emerged from our data, rather than individual differences. Future research may for instance, investigate differences across gender and/or seniority to understand how these factors influence the identity work of professionals and the experience of anxiety in different work contexts. Future research may also explore how identity issues in construction projects influence professionals' interactions with other members of the project team.

\section{Conclusion}

We have explored how one group of construction professionals - architects - manage their interactions with increasingly powerful and knowledgeable clients. Our analysis suggests that interactions with clients pose significant challenges to professionals' identity that can lead to ongoing anxieties. By adopting a sociologically informed, discursive approach to identity our research serves as a catalyst for construction management researchers to explore other 'individual level and socio-psychological constructs' (Phua, 2013: 176) and the implications for organizational performance and project outcomes. The conceptual framework proposed in 
this study could be used to investigate the interactions of other project actors (e.g., contractor, engineer, and project manager) with clients as they may illuminate identity challenges and anxieties in diverse project actor relationships. Finally, these findings should find a significant place in the future of architectural education and professional associations in order to better prepare professionals for contemporary practice.

\section{References}

Abbott A (1988) The System of Professions: An Essay on the Division of Expert Labor, Chicago: The University of Chicago Press.

Ahuja S, Heizmann H and Clegg S (2019) Emotions and Identity Work: Emotions as Discursive Resources in the Constitution of Junior Professionals' Identites. Human Relations 72(5): 988-1009.

Ahuja S, Nikolova N and Clegg S (2017) Paradoxical Identity: The Changing Nature of Architectural Work and its Relation to Architects' Identity. Journal of Professions and Organization 4(1): 2-19.

Ainsworth S and Hardy C (2004) Discourse and Identities. In: Grant D, Hardy C, Oswick C, et al. (eds) The Sage Handbook of Organizational Discourse. London: Sage, 153-174.

Akintoye A and Main J (2007) Collaborative Relationships in Construction: the UK Contractors' Perception. Engineering, Construction and Architectural Management 14(6): 597-617.

Allan S, Faulconbridge J and Thomas P (2018) The Fearful and Anxious Professional: Partner Experiences of Working in the Finacialized Professional Service Firm. Work, Employment \& Society: 1-19.

Alvesson M, Ashcraft K and Thomas R (2008) Identity Matters: Reflections on the Construction of Identity Scholarship in Organization Studies. Organization 15(1): 528. 
Alvesson M and Willmott H (2002) Identity Regulation as Organizational Control: Producing the Appropriate Individual. Journal of Management Studies 39(5): 619-644.

Anderson-Gough F, Grey C and Robson K (2000) In the Name of the Client: The Service Ethic in Two Professional Service Firms. Human Relations 53(9): 1151-1174.

Anteby M (2008) Identity Incentives as an Engaging Form of Control: Revisiting Leniencies in an Auronautic Plant. Organization Science 19(2): 202-220.

Ashman I and Gibson C (2010) Existential Identity, Ontological Security and Mental Wellbeing in th eworkplace. Contemporary Readings in Law and Social Justice 2(2): 126147.

Becker H, Geer B, EC H and Strauss A (1961) Boys in White, Chicago: Chicago University Press.

Beech N (2008) On the Nature of Dialogic Identity Work. Organization 15(1): 51-74.

Beech N, Gilmore C, Cochrane E and Greig G (2012) Identiy Work as a Response to Tensions: A Re-narration in Opera Rehersals. Scandinavian Journal of Management 28(1): 39-47.

Beech N, Gilmore C, Hibbert P and Ybema S (2016) Identity-in-the-Work and Musicians' Struggles: The Production of Self-Questioning Identity Work. Work, Employment \& Society 30(3): 506-522.

Blau J (1987) Architects and Firms: A Sociological Perspective on Architectural Practice, Cambridge MA: MIT Press.

Bos-De Vos M, Wamekink J and Volker L (2016) Trade-offs in the Value Capture of Architectural Firms: The Significance of Professional Value. Construction Management and Economics 34(1): 21-34.

Breakwell G (2010) Resisting Representations and Identity Processes. Papers on Social Representations 19(1): 6.1-6.11. 
Brown A (2017) Identity Work and Organizational Identification. International Journal of Management Reviews 19(3): 296-317.

Brown A and Coupland C (2015) Identity Threats, Identity Work and Elite Professionals. Organization studies 36(10): 1315-1336.

Brown A, Kornberger M, Clegg S and Carter C (2010) 'Invisible walls' and 'Silent hierarchies': A case study of power relations in an architectural firm. Human Relations 63(4): 525-549.

Brown A and Phua F (2011) Subjectively Construed Identities and Discourse: Towards a Research Agenda for Construction Management. Construction Management and Economics 29(1): 83-95.

Caven V and Diop M (2012) Architecture: A 'Rewarding' Career? An Anglo-French Comparative Study of Intrinsic Rewards in the Architecture Profession. Construction Management and Economics 30(7): 513-523.

Caza B, Vough H and Puranik H (2018) Identity Work in Organizations and Occupations: Definitions, Theories, and Pathways Forward. Journal of Organizational Behavior 39(7): 889-910.

Chan P (2016) Expert Knowledge in the Making: Using a Processual Lens to Examine Expertise in Construction. Construction Management and Economics 34(7-8): 471483.

Cherns A and Bryant D (1984) Studying the Client's Role in Construction Management. Construction Management and Economics 2(2): 177-184.

Cohen L, Wilkinson A, Arnold J and Finn R (2005) 'Remember I'm the bloody architect!' Architects, organizations and discourses of profession. Work, Employment \& Society 19(4): 775-796. 
COIB (2006) Occupational stress in the construction industry. UK: The Chartered Institute of Building.

Collinson D (2003) Identities and Insecurities: Selves at Work. Organization 10(3): 527-547. Cuff D (1991) Architecture: The Story of Practice, Cambridge: MIT Press.

Cuff D (2012) Introduction: Architecture's Double-Bind. In: Crysler CG and Hilde H (eds) The Sage Handbook of Architectural Theory. London: Sage, 385-393.

Dainty A, Green S and Bagilhole B (2007) People and Culture in Construction: Contexts and Challenges. In: Dainty A, Green S and Bagilhole B (eds) People and Culture in Construction: A Review. Abingdon: Taylor \& Francis, 3-25.

De Silva N, Samanmali R and De Silva H (2017) Managing Occupational Stress in Professionals in Large Construction Projects. Journal of Engineering, Design and Technology 15(4): 488-504.

Dick P and Hyde R (2006) Consent as Resistance, Resistance as Consent: Re-Reading PartTime Professionals' Acceptance of their Marginal Positions. Gender, Work and Organization 13(6): 543-564.

Dinovitzer R, Gunz H and Gunz S (2014) Unpacking Client Capture: Evidence from Corporate Law Firms. Journal of Professions and Organization 1(2): 99-117.

Duffy F and Rabeneck A (2013) Professionalism and Architects in the 21st Century. Building Research \& Information 41(1): 115-122.

Egan J (1998) Rethinking Construction: The Report of the Contruction Task Force to the Deputy Prime Minister on the Scope for Improving the Quality and Efficiency of UK Construction London: HMSO.

Farrell T (2014) The Farrell Review of Architecture and the Built Environment. UK. Fine G (1996) Justifying Work: Occupational Rhetorics as Resources in Restaurant Ktchens. Administrative Science Quarterly 41(1): 90-115. 
Frimpong S and Dansoh A (2018) Marginalization and Invasion of Architects' Role on House Projects: Institutional Intervention Inadequacy and Super Wicked Problems. Frontiers of Architectural Research 7(3): 292-303.

Gill M (2015) Elite Identity and Status Anxiety: An Interpretative Phenomenological Analysis of Management Consultants. Organization 22(3): 306-325.

Goffman E (1959) The Presentation of Self in Everyday Life, Harmondsworth: Penguin. Green S (1996) A Metaphorical Analysis of Client Organizations and the Briefing Process. Construction Management and Economics 14(2): 155-164.

Grey C (1998) On Being a Professional in a 'Big Six' Firm. Accounting, Organizations and Society 23(5/6): 569-587.

Groleau C, Demers C, Lalancette M and Barros M (2012) From Hand Drawings to Computer Visuals: Confronting Situated and Institutionalized Practices in an Architecture Firm. Organization Science 23(3): 651-671.

Gustafsson S, Swart J and Kinnie N (2017) 'They are your Testimony': Professionals, Clients and the Creation of Client Capture During Professional Career Progression. Organization studies 39(1): 73-92.

Gutman R (1988) Architectural Practice: A Critical Review, New York: Princeton Architectural Press.

Haines V and Saba T (2012) Challenges to Professional Identities and Emotional Exhaustion. Career Development International 17(2): 120-136.

Handley K, Clark T, Fincham R and Sturdy A (2007) Researching Situated Learning: Participation, Identity and Practices in Client- Consultant Relationships. Management Learning 38(2): 173-191. 
Havenvid M, Hulth en K, Linne A and Sundquist V (2016) Renewal in Construction Projects: Tracing effects of Client Requirements. Construction Management and Economics 34(11): 790-807.

Haynes N and Love P (2004) Psychological Adjustment and Coping Among Construction Project Managers. Construction Management and Economics 22(2): 129-140.

Heracleous L (2004) Interpretivist Approaches to Organizational Discourse. In: Grant D, Hardy C, Oswick C, et al. (eds) The Sage Handbook of Organizational Discourse. London: Sage.

Heynen H (2012) Genius, Gender and Architecture: The Star System as Exemplified in the Pritzker Prize. Architectural Theory Review 17(2): 331-345.

Hochschild A (1983) The Managed Heart: Commercialization of Human Feeling, Berkeley: University of California Press.

Hodgson D, Paton S and Muzio D (2015) Something Old, Something New?: Competing Logics and the Hybrid Nature of New Corporate Professions. British Journal of Management 26(1): 745-759.

Ibarra H (1999) Provisional Selves: Experimenting with Image and identity in Professional Adaptation. Administrative Science Quarterly 44(4): 764-791.

Jamieson C (2011) The Future for Architects? London: RIBA.

Jensen M (2006) Should we Stay or Should we Go? Accountability, Status Anxiety, and Client Defections. Administrative Science Quarterly 51(1): 97-128.

Johnson T (1972) Professions and Power, London: The Macmillan Press Ltd. Kanjanabootra S and Corbitt B (2016) Reproducing Knowledge in Construction Expertise: A Reflexive Theory, Critical Approach. Construction Management and Economics 34(7-8): 561-577. 
Knights D and Clarke C (2014) It's a Bittersweet Symphony, this Life: Fragile Academic Selves and Insecure Identities at Work. Organization studies 35(3): 335-357. Knights D and Clarke C (2018) Living on the Edge? Professional Anxieties at Work in Academia and Veterinary Practice. Culture and Organization 24(2): 134-153. Kreiner K (2009) Architectural Competitions - Empirical Observations and Strategic Implications for Architectural Firms. Nordisk Arkitekturforskning - Nordic Journal of Architectural Research 21(2/3).

Kuhn T (2009) Positioning Lawyers: Discursive Resources, Professional Ethics and Identification. Organization 16(5): 681-704.

Larson M (1993) Behind the Postmodern Facade: Architectural Change in Late TwentiethCentury America, Berkeley: University of California Press.

Latham M (1994) Constructing the Team: Final Report of the Government/Industry Review of Procurement and Contractual Arrangements in the UK Construction Industry. London: HMSO.

Lepisto D, Crosina E and Pratt M (2015) Identity Work within and Beyond the Professions: Towards a Theoretical Integration and Extension. In: Costa e Silva A and Aparicio M (eds) International Handbook of Professional Identities. USA: Scientific \& Academic Publishing, 11-37.

Lingard H (2003) The Impact of Individual and Job Characteristics on 'Burnout' Among Civil Engineers in Australia and the Implications for Employee Turnoever. Construction Management and Economics 21(1): 69-80.

Liu A and Walker A (1998) Evaluation of Project Outcomes. Construction Management and Economics 16(2): 209-219.

Lytle G and Orgel S (2014) Patronage in the Renaissance. Princeton: Princeton University Press. 
McGivern G, Currie G, Ferlie E, Fitzgerald L and Waring J (2015) Hybrid ManagerProfessionals' Identity Work: The Maintenance and Hybridization of Medical Professionalism in Mangerial Contexts. Public Administration 93(2): 412-432. McNeill D (2009) The Global Architect: Firms, Fame and Urban Form, London: Routledge. Miron-Spektor E and Erez M (2017) Looking at Creativity Through a Paradox Lens: Deeper Understanding and New Insights. In: Smith W, Lewis M, Jarzabkowski P, et al. (eds) The Oxford Handbook of Organizational Paradox.

Murtagh N, Roberts A and Hind R (2016) The Relationship Between Motivations of Architectural Designers and Environmentally Sustainable Construction Design. Construction Management and Economics 34(1): 61-75.

Muzio D and Ackroyd S (2005) On the Consequences of Defensive Professionalism: Recent Changes in the legal Labour Process. Journal of Law and Society 32(4): 615-642.

Ness K (2010) The Discourse of 'respect for People' in UK Construction. Construction Management and Economics 28(5): 482-493.

Nikolova N, Reihlen M and Schlapfner J (2009) Client-Consultant Interaction: Capturing Social Practices of Professional Service Production. Scandinavian Journal of Management 25(3): 289-298.

Peirce C (1934) Collected Papers of Charles Sanders Peirce. In: Hartshorne C and Weiss P (eds) Pragmatism and Pragmaticism. Cambridge, MA: Harvard University Press. Pelkonen E (2012) Architect as Organizer OR the Way the World Works. Perspecta, The Yale Architectural Journal 45(1): 7-16.

Petriglieri G, Ashford S and Wrzesniewski A (2018) Agony and Ecstasy in the Gig Eonomy: Cultivating Holding Environments for Precarious and Personalized Work Identities. Administrative Science Quarterly 64(1): 124-170. 
Phua F (2013) Construction Management Research at the Individual Level of Analysis: Current Status, Gaps and Future Directions. Construction Management and Economics 31(2): 167-179.

Pratt M, Rockmann K and Kaufmann J (2006) Constructing Professional Identity: The Role of Work and Identity Learning Cycles in the Customization of Identity Among Medical Residents. Academy of Management Journal 49(2): 235-262.

Reed C and Thomas R (2019) Embracing Indeterminancy: On Being a Liminal Professional. British Journal of Management 00(1-16.

RIBA (2015) Client and Architect: Developing the Essential relationship. London: Royal Institute of British Architects.

Robertson M, Scarbrough H and Swan J (2003) Knowledge Creation in Professional Service Firms: Institutional Effects. Organization studies 24(6): 831-857.

Samuel F (2018) Why Architects Matter: Evidencing and Communicationg the Value of Architects, Abington, Oxon: Routledge.

Schein E (1997) The concept of 'client' from a process consulation perspective: A guide for change agents. Journal of Organizational Change Management 10(3): 202-216.

Sergeeva N and Green S (2019) Mangerial Identity Work in Action: Performative Narratives and Anecdotal Stories of Innovation. Construction Management and Economics 37(10): 1-20.

Sherratt F, Farrell P and Noble R (2013) UK Construction Site Safety: Discourses of Enforcement and Engagement. Construction Management and Economics 31(6): 623635.

Sturdy A (1997) The Consultancy Process - An Insecure Business. Journal of Management Studies 34(3): 389-413. 
Sveningsson S and Alvesson M (2003) Managing Managerial Identities: Organizational Fragmentation, Discourse and Identity Struggle. Human Relations 56(10): 1163-1193. Thomas P and Hewitt J (2011) Managerial Organization and Professional Autonomy: A Discourse-Based Conceptualization. Organization studies 32(10): 1373-1393. van Maanen J, Sørensen J and Mitchell T (2007) Introduction to Special Topic Forum: The Interplay Between Theory and Method. Academy of Management Review 32(4): $1145-1154$.

van Marrewijk A, Ybema S, Smits k, Clegg S and Pitsis T (2016) Clash of the Titans: Temporal Organizing and Collaborative Dynamics in the Panama canal Megaproject. Organization studies 37(12): 1745-1769.

Vough H, Cardador M, Bednar J, Dane E and Pratt M (2013) What Clients Don't get About my Profession: A Model of Percieved Role-Based Image Discrepancies. Academy of Management Journal 56(4): 1050-1080.

Wade F, Murtagh N and Hitchings R (2017) Managing Professional Jurisdiction and Domestic Energy Use. Building Research \& Information 46(1): 42053.

Waite R and Braidwood E (2017) Q\&A: Architects on Marginalization and What Can Be Done About It. Achitects' Journal (AJ). UK.

Winch G and Schneider E (1993) The Strategic Management of Architectural Practice. Construction Management and Economics 11(6): 467-473.

Wiscombe T (2006) Emergent Models of Architectural Practice: Architecture after All. Perspecta, The Yale Architectural Journal 38(57-68.

Wright C, Nyberg N and Grant D (2012) "Hippies on the third floor": Climate Change, Narrative Identity and the Micro-Politics of Corporate Environmentalism. Organization studies 33(11): 1451-1475. 


\begin{tabular}{|c|c|c|c|}
\hline Organization & $\begin{array}{l}\text { Work } \\
\text { undertaken }\end{array}$ & $\begin{array}{c}\text { Number } \\
\text { interviewed }\end{array}$ & Respondents \\
\hline Firm 1 & $\begin{array}{l}\text { Transport, } \\
\text { health, } \\
\text { education, } \\
\text { commercial, } \\
\text { sports, } \\
\text { residential, } \\
\text { conservation, } \\
\text { public realm }\end{array}$ & 12 & $\begin{array}{l}\text { Renowned } \\
\text { architect (1), } \\
\text { Directors (2), } \\
\text { senior } \\
\text { associates (4), } \\
\text { architects (3) } \\
\text { Juniors (2) }\end{array}$ \\
\hline Firm 2 & $\begin{array}{l}\text { Transport, } \\
\text { health, } \\
\text { commercial, } \\
\text { sports, } \\
\text { residential, } \\
\text { public realm }\end{array}$ & 16 & $\begin{array}{l}\text { Renowned } \\
\text { architect (1), } \\
\text { Directors (1), } \\
\text { senior } \\
\text { associates (5), } \\
\text { project } \\
\text { architects (4) } \\
\text { Juniors (5) }\end{array}$ \\
\hline Firm 3 & $\begin{array}{l}\text { Commercial, } \\
\text { residential, } \\
\text { retail, sports, } \\
\text { education, } \\
\text { defence }\end{array}$ & 12 & $\begin{array}{l}\text { Senior } \\
\text { associates (2), } \\
\text { project } \\
\text { architects (4), } \\
\text { architects (4) } \\
\text { Juniors (2) }\end{array}$ \\
\hline Firm 4 & $\begin{array}{l}\text { Transport, } \\
\text { residential, } \\
\text { commercial, } \\
\text { retail }\end{array}$ & 10 & $\begin{array}{l}\text { Senior } \\
\text { associates (2), } \\
\text { project } \\
\text { architects (1), } \\
\text { architects (3) } \\
\text { Juniors (4) }\end{array}$ \\
\hline Total & & 50 & \\
\hline
\end{tabular}

\begin{tabular}{l|l}
\hline Table 2 Participant Information & \\
\hline Participant & Professional tenure (yrs.) \\
\hline Director/Principle & $>20$ \\
Senior Associate & $>15$ \\
Project Architect & $>12$ \\
Architect (licenced) & $>10$ \\
Junior architect (not licensed) & $<5$ \\
\hline
\end{tabular}

